\title{
Azot uygulamalarının ekmeklik buğday çeşitlerinin tane sterol (campesterol, stigmasterol ve betasitosterol) konsantrasyonuna etkisi*
}

\author{
Yener Kortan TOSUN¹, Halil ERDEM² ${ }^{\text {, Cabir Çağrı GENCE }}{ }^{3}$ \\ ${ }^{1}$ Bozok University, Vocational School of Technical Science, Plant and Animal Production, 66200, Yozgat, Turkey. \\ ${ }^{2}$ Gaziosmanpasa University, Faculty of Agriculture, Soil Science and Plant Nutrition Department, 60240, Tokat, Turkey. \\ ${ }^{3}$ Aksaray Üniversitesi, Bilimsel ve Teknolojik Uygulama ve Araştırma Merkezi, 68100, Aksaray, Turkey. \\ * Ekmeklik Buğday Çeşitlerinin Fitosterol İçeriklerinin Bitki Besin Elementleri İle İlişkilerinin Araștırılması Doktora Tezi \\ Alınış tarihi: 26 Mart 2018, Kabul tarihi: 4 Eylül 2018 \\ Sorumlu yazar: Halil ERDEM, e-posta:erdemh@hotmail.com
}

\section{$\ddot{0} z$}

Bitki sterolleri (fitosterol) insan sağlı̆̆ için çeşitli biyoaktif özelliklere sahip bir grup steroid alkoldür Fitosteroller kolesterolün bağırsaktaki emilimini engelleyerek kandaki kolesterol seviyelerini düşürücü etkiye sahiptirler. Bu çalışmanın amacı sera koşullarında iki farklı ekmeklik buğday çeşidine (Yunus ve Osmaniyem) azot (N) uygulamalarının tane Campesterol, Stigmasterol ve Betasitosterol konsantrasyonlarına olan etkisi araştırılmıştır. Çalıșmada N uygulamaları topraktan 250 ve $500 \mathrm{mg} \mathrm{kg}^{-1}$ dozlarında yapılmış, $500 \mathrm{mg} \mathrm{kg}^{-1} \mathrm{~N}$ uygulamasına ayrıca üç farklı dönemde (sapa kalkma, başaklanma ve tane olum) yapraktan \% 0.5 üre verilmiştir. Azot uygulaması ile hem Yunus hem de Osmaniyem çeşitlerinin tane $\mathrm{N}$ konsantrasyonlarında istatistiksel olarak önemli artışlar görülmüştür. Azot uygulaması ile Yunus çeşidinin tanesinde \%89, Osmaniyem çeşidinde ise \%62'lik bir N konsantrasyonu artışı meydana gelmiştir. Azot uygulaması ile tane N konsantrasyonlarında görülen artışa paralel olarak Yunus çeşidinin Campesterol konsantrasyonunda \%45, Stigmasterol konsantrasyonunda \%145 ve Betasitosterol konsantrasyonunda ise \%105 düzeyinde bir artış olduğu görülmüștür. Osmaniyem çeșidinin Campesterol konsantrasyonunda \%99, Stigmasterol konsantrasyonunda \%38, Betasitosterol konsantrasyonunda ise \%73 artış meydana gelmiştir. Elde edilen sonuçlardan N'un Campesterol, Stigmasterol ve Betasitosterol yapısına katılma ihtimalinin yüksek olduğu görülmektedir.

Anahtar kelimeler: Azot, Campesterol, Stigmasterol, Betasitosterol, ekmeklik buğday
Effect of bread wheat varieties on grain sterol (campesterol, stigmasterol and betasitosterol) concentration of nitrogen applications

\begin{abstract}
Plant sterols (phytosterols) are a group of steroidal alcohols with various bioactive properties for human health. Phytosterols inhibit cholesterol absorption in the intestine and have a lowering effect on the immediate cholesterol levels. In this study, the effect of nitrogen applications on the concentration of Campesterol, Stigmasterol and Betasitosterol of two different bread wheat types (Yunus and Osmaniyem) in the greenhouse was investigated. Nitrogen applications were carried out in 250 and $500 \mathrm{mg} \mathrm{kg}^{-1}$ doses as the soil fertilizing and also $500 \mathrm{mg} \mathrm{kg}^{-1}$ nitrogen were sprayed to the leaves by using $0.5 \%$ urea in three (booting, anthesis, milk) different periods. Nitrogen application showed significant increases in grain $\mathrm{N}$ concentrations of both Yunus and Osmaniyem varieties. Nitrogen application has increased of $89 \%$ in grain $\mathrm{N}$ concentration of Yunus varieties and $62 \%$ in Osmaniyem varieties. In the $\mathrm{N}$ concentration by nitrogen application, an increase of $45 \%$ in the Campesterol, $145 \%$ in the concentration of stigmasterol and $105 \%$ in the concentration of betasitosterol was observed in the grain of Yunus varieties. There was a rise of $99 \%$ in the Campesterol, $38 \%$ in the stigmasterol and 73\% in the betacitosterol of the Osmaniyem varieties. The possibility of nitrogen's participating in stain of Campesterol, Stigmasterol and Betasitosterol seems to be high.
\end{abstract}

Key words: Nitrogen, campesterol, stigmasterol, betasitosterol, bread wheat 


\section{Giriş}

Son yıllardaki bilimsel çalışmalar dengeli beslenme, diyet ve hastalıklar arasındaki ilişkiyi açık bir șekilde ortaya koymuş olup, epidemiyolojik çalışmalar diyetin kronik hastalıkların önlenmesindeki rolüne işaret etmektedir. Beslenme alışkanlıklarının daha fazla meyve, sebze ve tahıl tüketecek şekilde değiştirilmesi kronik hastalıkların önlenmesinde etkin ve pratik bir yaklașımdır (Coșkun, 2005). Hastalıklarla mücadele konusunda etkin olan diğer bir faktör de bitkisel ürünlerdir. Bitkilerde bulunan karotenoidler, antioksidan vitaminler, fenolik bileșikler, terpenoidler, steroller, indoller ve liflerin kronik hastalık riski azaltılmasında önemli rol oynadığı bildirilmiștir. Özellikle bitkilerde bulunan steroller, fitosteroller olarak isimlendirilirler. Fitosteroller; triterpen ailesine ait steroid alkolleridir (Nurmi, 2012). Yapıları kolesterole çok benzemekle birlikte fazladan etil veya metil grubu ve yan zincirde çift bağ içerirler. Fitosteroller bitkilerde serbest alkoller şeklinde ya da onların çökeltileri halinde bulunurlar (Nurmi, 2012). Fitosteroller bitkisel ürünlerde özellikle bitkisel yağlarda doğal halde bulunurlar. Fitosterollerin insan sağlığına etkisi üzerine yapılan bir araştırmada, bireylerin fitosterol alımı ile düşük yoğunluklu lipoprotein yani kolestrol düşürücü etkilerinin olduğu, ancak bireyler arasındaki kolesterol düşürmenin derecesinin çeşitli faktörlere bağlı olarak değişebildiği bildirilmiştir (Rudkowska, 2010). Fitosterollerin kolesterol düşürme etkilerinin yanı sıra anti inflamatuar, anti aterojenik (kardiyovasküler sağlı̆̆ destekleyen ve kalp krizi, felç ve diğer kardiyovasküler hastalıkların ve plak oluşumunu önleyen) ve antioksidan gibi sağlık üzerine olumlu etkileri ve anti kanser gibi koruyucu etkileri de görülmektedir (Rudkowska, 2010). Yenebilir yağlar ve bu yağlardan üretilen ürünler zengin sterol kaynaklarıdır (Abidi, 2001). Tahıl ve tahıl ürünleri, yağlı tohumlardan düşük miktarda fitosterol içermelerine karşın, tüketim oranlarıyla karşıllaştırıldığında tahıllar insan beslenmesinde daha fazla yer almaktadırlar (Taşan, 2008). Beslenmedeki en yaygın tahıl çeşitleri ise buğday, mısır ve pirinçtir (Anonim, 2012). Bunlardan buğday dünya nüfusunun beslenmesinde yer alan en önemli tahıldır (Nurmi ve ark., 2008). Buğdayda fazla miktarlarda bulunan başlıca sterollerin Betasitosterol, Campesterol ve Stigmasterol olduğu bildirilmiştir (Moreau et al., 2002). Buğdaydan elde edilen ekmek ve tahıllar, fitosterol konsantrasyonları bakımından tahıllar ve tahıllardan yapılan yiyecekler olarak ayrıca gruplandırılmaktadırlar (El, 2008).
Türkiye'de ekmek tüketimi fazla olup, enerji ihtiyacının büyük bir kısmı ekmekten karşılanmaktadır. Özellikle B grubu vitaminler bașta olmak üzere, Ca, $\mathrm{Fe}, \mathrm{Zn}$ gibi mineral maddeler ve amino asitler, buğdayın kabuk ve embriyo kısmında yüksek, endosperminde düşük konsantrasyonlarda bulunmaktadır (Kotancılar ve ark., 1995). Fitosterol miktarının artırılması bitkileri tüketen insanlarda serum kolesterol miktarının düşmesine sebep olacaktır. Azot bitkiler için önemli bir besin elementidir. Bitkilerdeki N'lu bileşiklerin en önemlileri aminoasitler, dolayısıyla proteinlerdir. Azot, bitkilerde proteinin yanısıra, kalıtım materyali olan nükleik asitlerin de yapısına girer ve çeşitli enzimlerin koenzim kısmını oluşturan bazı vitaminlerde de bulunur (Hewitt ve Smith, 1974; Xu ve ark., 2012). Tahıl ve tahıl ürünlerinin fitosterol miktarlarının miktar ve çeşitliliği ile ilgili çeşitli çalışmalar olmasına rağmen bu bilgilerin hala sınırlı olduğu Piironen et al. (2000), tarafindan ifade edilmektedir. Fitosteroller ve bitki besin elementleri arasındaki ilişki hakkında çok fazla çalışmalara rastlanmamıştır. Bu çalışmanın amacı sera koşullarında iki farklı ekmeklik buğday çeşidine $\mathrm{N}$ uygulamalarının dane streol konsantrasyonuna olan etkisi araştırilmıștır.

\section{Materyal ve Metod}

\section{Materyal}

Deneme Çukurova Üniversitesi Ziraat Fakültesi Toprak Bilimi ve Bitki Besleme Bölümü Araştırma Seralarında iki ekmeklik buğday çeşidi kullanılarak gerçekleştirilmiştir. Deneme toprağının pH'sı 8.83, kireci \%17.8, organik maddesi \% 0.12 , tuzu $0.24 \mathrm{mS}$, yarayışlı $\mathrm{P}$ konsantrasyonu $0.26 \mathrm{mg} \mathrm{kg}{ }^{-1}$, $\mathrm{K}$ konsantrasyonu $154 \mathrm{mg} \mathrm{kg}^{-1}$, DTPA'da ekstakte edilebilir $\mathrm{Zn}$ konsantrasyonu $0.11 \mathrm{mg} \mathrm{kg}^{-1}$, Fe konsantrasyonu $2.84 \mathrm{mg} \mathrm{kg}^{-1}$, tekstürü ise killidir.

\section{Metod}

\section{Denemenin kurulması ve yürütülmesi}

Sera denemesinde bitkiler iki farklı N dozunda (250 ve $500 \mathrm{mg} \mathrm{kg}^{-1} \mathrm{~N}$ ) yetiştirilmiştir. Denemede $250 \mathrm{mg}$ $\mathrm{kg}^{-1} \mathrm{~N}$ dozu kontrol (N250) olarak, topraktan $500 \mathrm{mg}$ $\mathrm{kg}^{-1}$ uygulamasina (N500) ek olarak bu doza sahip bitkilere ayrıca bitkiler sapa kalkma, başaklanma ve tane olum dönemlerinde iken üç farklı zamanda yapraktan \%0.5 üre uygulaması yapılmıştır. Topraktan $500 \mathrm{mg} \mathrm{kg}^{-1} \mathrm{~N}$ uygulamasına ilave olarak yapılan yapraktan üre uygulamasının amacı tanenin $\mathrm{N}$ konsantrasyonunu arttırmaktır. Denemede temel gübreleme olarak tüm saksılara $100 \mathrm{mg} \mathrm{kg}^{-1} \mathrm{P}\left(\mathrm{KH}_{2} \mathrm{PO}_{4}\right.$ formunda), $50 \mathrm{mg} \mathrm{kg}^{-1} \mathrm{~S}$ ( $\mathrm{CaSO}_{4} .2 \mathrm{H}_{2} \mathrm{O}$ formunda) 
$2.5 \mathrm{mg} \mathrm{kg}^{-1} \mathrm{Fe}$ (Fe-EDTA formunda) ve $2.5 \mathrm{mg} \mathrm{kg}^{-1} \mathrm{Zn}$ $\left(\mathrm{ZnSO}_{4} .7 \mathrm{H}_{2} \mathrm{O}\right.$ formunda) topraklara çözelti şeklinde karıștırılarak uygulanmıştır. Azot uygulamaları $\mathrm{Ca}\left(\mathrm{NO}_{3}\right)_{2} .4 \mathrm{H}_{2} \mathrm{O}$ formunda ve denemenin kurulması aşamasında diğer temel gübreler ile birlikte uygulanmıştır. Saksı başına 12 tohum ekilmiş ve çimlenmeden sonra bu sayı 5'e seyreltilmiştir. Bitkilerin su ihtiyacı hasat zamanına kadar saf su ile ve tarla kapasitesine yakın (\%70 civarında) bir nem içeriğinde olacak şekilde yapılmıştır. Bitkiler başak olgunlaşma sonunda hasat edilmiș, hasat ișleminden sonra bitkilerin verimi (toplam biyomas) ve tane verimi belirlenmiștir.

\section{Tane örneklerinde mineral element analizleri}

Hasat edilen tane örnekleri mikrodalga cihazında yaş yakma metoduna göre $\mathrm{H}_{2} \mathrm{O}_{2}-\mathrm{HNO}_{3}$ asit karışımında yakılmıştır. Elde edilen süzüklerde $\mathrm{P}, \mathrm{K}, \mathrm{Zn}$ ve $\mathrm{Fe}$ konsantrasyonları ICP-OES (Varian Vista) cihazında belirlenmiştir (Kaçar ve İnal, 2008). Tane örneklerinde $\mathrm{N}$ analizi ise Kjeldahl destilasyon yöntemine göre yapılmıştır (Bremner, 1965).

\section{Tane örneklerinde fitosterol analizleri}

Araştırmada kullanılan çeşitlerin tanelerinde bulunan fitosterol içerikleri Analitik Kimyacılar Birliği metodu (Association of Official Analytical Chemists Official Method-AOAC) "994.10" yöntemi kullanılarak (AOAC, 2000), Gaz Kromatografisi-Kütle Spektrometresi (GC-MS) cihazında analiz edilmiştir.

\section{Verilerin değerlendirilmesi}

Fitosteroller ile N arasındaki ilişkinin düzeyini belirleme amacı ile korelasyon testi yapılmıștır. Her bir özelliğin aritmetik ortalama, standart sapma ve varyasyon katsayısı hesaplanmış ve normalite testi uygulanmıştır. Bitki özellikleri arasındaki korelasyonlar ile fitosterol oluşumunu en çok etkileyen besin elementleri ve etki miktarı belirlenmiştir. Uygulamalar arasındaki farklılıklar Duncan analiz yöntemi ile belirlenmiştir. İstatistiksel analizler için SPSS 21 paket programı kullanılmıştır.

\section{Bulgular ve Tartışma}

Azot uygulamalarının Yunus ve Osmaniyem buğday çeşitlerinin verim, tane mineral element ve fitosterol konsantrasyonlarına olan etkisi Çizelge 1 ve 2'de verilmiştir. N250 uygulamasına göre toprak + yapraktan $\mathrm{N}$ uygulaması ile çeşitlerin hem bitki verimi hem de tane veriminde artışların olduğu görülmüş, ancak bu artışın istatistiksel olarak Yunus çeşidinde önemli olmadığı, Osmaniyem çeşidinde ise bitki ve- riminde önemsiz, tane veriminde ise önemli olduğu görülmüştür. Buna karşın N uygulaması ile hem Yunus hem de Osmaniyem çeşitlerinin tane N konsantrasyonlarında istatistiksel olarak önemli artışların olduğu görülmüştür. Yunus çeşidinin kontrol uygulamasinda tane $\mathrm{N}$ konsantrasyonu \%1.37 iken, toprak+yapraktan $\mathrm{N}$ uygulaması ile ile tane $\mathrm{N}$ konsantrasyonu \%2.35'e çıkmıştır. Osmaniyem çeşidinde ise N250 uygulamasinda \%1.53 olan N konsantrasyonu N500+\%0.5 üre uygulamasında \% 2.49'a çıkmıştır. Azot uygulaması ile Yunus çeşidinin tanesinde \%89, Osmaniyem çeşidinde ise \%62'lik bir konsantrasyon artışı meydana gelmiştir (Çizelge 1, Şekil 1). Bly ve Woodart (2003), iki farklı buğday çeşidine iki farklı zamanda (sapa kalkma ve başaklanma) yapraktan üre (33.7 $\mathrm{kg} \mathrm{N} \mathrm{ha}^{-1}$ ) uygulaması ile tane $\mathrm{N}$ içeriğinde \% 70'lik bir konsantrasyon artışının olduğunu, bunun yanında kontrol uygulamasına göre tane veriminde de istatistiksel olarak artışın olduğunu bildirmişlerdir. Haile ve ark. (2012), tarla koşullarında

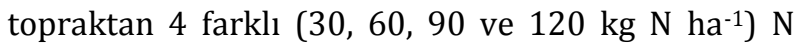
uygulamasının iki farklı ekmeklik buğday çeşidinde hem verimde hem de $\mathrm{N}$ dozunda önemli artışların olduğunu bildirmişlerdir. Azotun 30 dozunda 3396 $\mathrm{kg} \mathrm{ha}^{-1}$ olan her iki çeşidin ortalama verimi, N120 dozunda $4252 \mathrm{~kg} \mathrm{ha}^{-1}$ 'a çlkmış, tane N konsantrasyonu ise N30 dozunda \% 1.98 iken N120 dozunda $\% 2.10$ 'a çlkmıştır. Topraktan ve yapraktan N uygulaması (N500) ile Yunus ve Osmaniyem buğday çeșitlerinin tanelerinde meydana gelen $\mathrm{N}$ konsantrasyon artışına benzer şekilde her iki çeşidin Campesterol, Stigmasterol ve Betasitosterol dozlarında önemli $(\mathrm{p}<0.01)$ oranlarda artışlar görülmüştür (Çizelge 2; Şekil 2). Yunus çeşidinin N250 dozu koşullarında $4.14 \mathrm{mg} \mathrm{kg}^{-1}$ olan Campesterol konsantrasyonu N500+\%0.5 üre koşullarında $6.01 \mathrm{mg} \mathrm{kg}^{-1}$ 'a (\%45 artış), Stigmasterol konsantrasyonu N250 dozunda $1.18 \mathrm{mg} \mathrm{kg}^{-1}$ iken $\mathrm{N} 500+\% 0.5$ üre dozunda ise 2.89 mg kg-1'a (\%145 artış), Betasitosterol konsantrasyonu N250 dozunda $73.0 \mathrm{mg} \mathrm{kg}^{-1}$ iken N500+\%0.5 üre dozunda $150.2 \mathrm{mg} \mathrm{kg}^{-1}$ 'a (\%105 artış) çıktığı görülmüştür. Osmaniyem çeşidinin N250 koşullarında $7.09 \mathrm{mg} \mathrm{kg}^{-1}$ olan Campesterol konsantrasyonu N500+\%0.5 üre koșullarında $14.13 \mathrm{mg} \mathrm{kg}^{-1}$ 'a (\%99 artış), Stigmasterol konsantrasyonu N250 dozunda $2.95 \mathrm{mg} \mathrm{kg}^{-1}$ iken $\mathrm{N} 500+\% 0.5$ üre dozunda ise 4.06 mg kg-1'a (\%38 artış), Betasitosterol konsantrasyonu N250 dozunda $176.8 \mathrm{mg} \mathrm{kg}^{-1}$ iken N500+\%0.5 üre dozunda $306.4 \mathrm{mg} \mathrm{kg}^{-1}$ 'a (\%73 artış) çıktığı görülmüştür (Çizelge 2; Şekil 2). 
Çizelge 1. Topraktan (N250) ve toprak+yapraktan (N500+\%0.5 üre) uygulamasının Yunus ve Osmaniyem çeşitlerinin bitki verimi, tane verimi ve mineral element konsantrasyonlarına etkisi

\begin{tabular}{|c|c|c|c|c|c|c|c|}
\hline \multirow[b]{2}{*}{ Çeşit } & \multirow[b]{2}{*}{ Özellik } & \multicolumn{2}{|c|}{ Azot Uygulaması } & \multicolumn{4}{|c|}{ T-Testi } \\
\hline & & $\begin{array}{c}\mathrm{N} 250 \\
\left(\mathrm{~T}^{*}\right)\end{array}$ & $\begin{array}{c}\mathrm{N} 500 \\
\left(\mathrm{~T}+\mathrm{Y}^{* *}\right)\end{array}$ & $\begin{array}{c}\text { Ortalama } \\
\text { Farkl }\end{array}$ & Std. sapma & Std. hata & Önem \\
\hline \multirow{7}{*}{ Yunus } & Bitki Verimi (gr bitki-1) & 9.76 & 10.93 & -1.18 & 2.52 & 1.26 & ns \\
\hline & Tane Verimi (gr bitki-1) & 2.18 & 2.35 & -0.17 & 0.35 & 0.18 & ns \\
\hline & $\mathrm{N}(\%)$ & 1.37 & 2.59 & -1.22 & 0.39 & 0.20 & $* *$ \\
\hline & $\mathrm{K}(\%)$ & 0.50 & 0.45 & 0.05 & 0.02 & 0.01 & $*$ \\
\hline & $\mathrm{P}(\%)$ & 0.35 & 0.35 & 0.00 & 0.02 & 0.01 & ns \\
\hline & $\mathrm{Fe}\left(\mathrm{mg} \mathrm{kg}^{-1}\right)$ & 33.5 & 41.60 & -8.11 & 11.14 & 5.57 & ns \\
\hline & $\mathrm{Zn}\left(\mathrm{mg} \mathrm{kg}^{-1}\right)$ & 23.2 & 32.1 & -8.89 & 6.63 & 3.32 & ns \\
\hline \multirow{7}{*}{ Osmaniyem } & Bitki Verimi (gr bitki-1) & 7.23 & 7.96 & -0.74 & 0.52 & 0.26 & ns \\
\hline & Tane Verimi (gr bitki-1) & 2.44 & 3.28 & -0.84 & 0.23 & 0.12 & $*$ \\
\hline & $\mathrm{N}(\%)$ & 1.53 & 2.49 & -0.95 & 0.17 & 0.09 & $*$ \\
\hline & $\mathrm{K}(\%)$ & 0.48 & 0.44 & 0.03 & 0.06 & 0.03 & ns \\
\hline & $\mathrm{P}(\%)$ & 0.33 & 0.28 & 0.05 & 0.06 & 0.03 & ns \\
\hline & $\mathrm{Fe}\left(\mathrm{mg} \mathrm{kg}^{-1}\right)$ & 23.43 & 32.64 & -9.21 & 4.38 & 2.19 & $*$ \\
\hline & $\mathrm{Zn}\left(\mathrm{mg} \mathrm{kg}^{-1}\right)$ & 20.6 & 25.1 & -4.50 & 6.16 & 3.08 & ns \\
\hline
\end{tabular}

**: p<0.01; *:p<0.05 önem seviyesinde; ; *T: Topraktan 250 mg kg-1 N uygulaması, **T+Y: Topraktan 500 mg kg-1 N ve yapraktan \%0.5 üre uygulaması

Çizelge 2. Topraktan (N250) ve toprak+yapraktan (N500+\%0.5 üre) Azot (N) uygulamasının Yunus ve Osmaniyem çeşitlerinin campesterol, stigmasterol ve betasitosterol konsantrasyonlarına etkisi

\begin{tabular}{|c|c|c|c|c|c|c|c|}
\hline \multirow[b]{2}{*}{ Çeşit } & \multirow[b]{2}{*}{ Özellik } & \multicolumn{2}{|c|}{ Azot Uygulaması } & \multicolumn{4}{|c|}{ T-Testi } \\
\hline & & $\begin{array}{c}\mathrm{N} 250 \\
\left(\mathrm{~T}^{*}\right)\end{array}$ & $\begin{array}{c}\mathrm{N} 500 \\
\left(\mathrm{~T}+\mathrm{Y}^{* *}\right)\end{array}$ & $\begin{array}{c}\text { Ortalama } \\
\text { Farkl }\end{array}$ & $\begin{array}{c}\text { Std. } \\
\text { sapma }\end{array}$ & Std. hata & Önem \\
\hline \multirow{4}{*}{ Yunus } & Bitki Verimi (gr bitki-1) & Campesterol $\left(\mathrm{mg} \mathrm{kg}^{-1}\right)$ & 4.14 & 6.01 & -1.87 & 0.50 & 0.25 \\
\hline & Tane Verimi (gr bitki ${ }^{-1}$ ) & Stigmasterol $\left(\mathrm{mg} \mathrm{kg}^{-1}\right)$ & 1.18 & 2.89 & -1.71 & 0.08 & 0.04 \\
\hline & $\mathrm{N}(\%)$ & Beta Sitosterol (mg kg-1) & 73.0 & 150.2 & -77.20 & 7.09 & 3.55 \\
\hline & $\mathrm{K}(\%)$ & Campesterol (mg kg-1) & 7.09 & 14.13 & -7.04 & 0.35 & 0.18 \\
\hline \multirow{4}{*}{ Osmaniyem } & Bitki Verimi (gr bitki-1) & Stigmasterol $\left(\mathrm{mg} \mathrm{kg}^{-1}\right)$ & 2.95 & 4.06 & -1.12 & 0.03 & 0.02 \\
\hline & Tane Verimi (gr bitki ${ }^{-1}$ ) & Beta Sitosterol $\left(\mathrm{mg} \mathrm{kg}^{-1}\right)$ & 176.8 & 306.4 & -129.63 & 2.33 & 1.17 \\
\hline & $\mathrm{N}(\%)$ & Campesterol (mg kg-1) & 4.14 & 6.01 & -1.87 & 0.50 & 0.25 \\
\hline & $\mathrm{K}(\%)$ & Stigmasterol $\left(\mathrm{mg} \mathrm{kg}^{-1}\right)$ & 1.18 & 2.89 & -1.71 & 0.08 & 0.04 \\
\hline
\end{tabular}

**: p<0.01; *:p<0.05 önem seviyesinde; *T: Topraktan 250 mg kg-1 N uygulaması, ${ }^{* *} \mathrm{~T}+\mathrm{Y}$ : Topraktan $500 \mathrm{mg}$ kg-1 N ve yapraktan $\% 0.5$ üre uygulaması

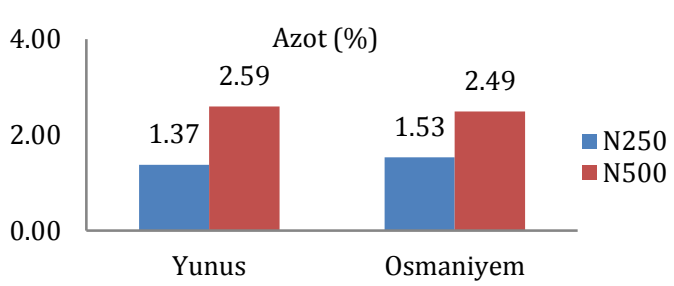

Şekil 1. Topraktan ve toprak+yapraktan $\mathrm{N}$ uygulamasının Yunus ve Osmaniyem çeşitleri tane $\mathrm{N}$ konsantrasyonlarına etkisi

Çizelge 3'de verilen varyans analiz tablosuna göre Campesterol, Stigmasterol ve Betasitosterol konsantrasyonlarında meydana gelen artışın topraktan ve yapraktan $\mathrm{N}$ uygulamasından önemli ölçüde etkilendiği ortaya çıkmıştır. Azot uygulaması ile hem Yunus hem de Osmaniyem çeşitlerinin Campesterol, Stigmasterol ve Betasitosterol konsantrasyonlarında meydana gelen artış istatistiksel olarak önemlidir $(p<0.01)$. Bitkilerdeki azotlu bileşiklerin en önemlileri aminoasitler, dolayısıyla proteinlerdir. Azot, bitkilerde sadece proteinlerin yapısına değil, kalıtım materyali olan nükleik asitlerin yapısına girer ve çeşitli enzimlerin koenzim kısmını oluşturan bazı vitaminlerde de bulunur (Hewitt and Smith, 1974; $\mathrm{Xu}$ et al., 2012). Bunun yanında Apocyanacae, Papaveraceae, Ranunculaceae ve Solanaceae gibi familyaların üyelerinde rastlanan alkaloitler de azotlu bileşiklerdendir. Bitki sterolleri serbest hidroksil grubu protein ve fosfolipidler arasındaki interaksiyonu sağlayan önemli bir bileşendir. Steroller birkaç özel sterolün hareketini kapsayan hücre zarına bağlı metabolik süreçlerin kontrolüne katılırlar. Steroller, aynı zamanda brassinosteroidler için ön madde olarak bitkilerde hücre ve gelişme süreçlerinde önemli bir rol oynamaktadır (Piironen et al., 2000). Gül ve ark. (2007), 19 farklı kanola (Brassicanapus L.) genotipine iki farklı dozda (0 ve $130 \mathrm{~kg} \mathrm{~N} / \mathrm{ha}$ ) N uygulaması yaparak genotiplerin fitosterol konsantrasyonlarında meydana gelen değişimi incelemişlerdir. Araştırıcılar kontrol koşullarında 1292 mg kg-1 olan campesterol konsantrasyonunun $130 \mathrm{~kg} \mathrm{~N} / \mathrm{ha}$ uygu- 
lamasında $1246 \mathrm{mg} \mathrm{kg}^{-1}$ ' a düștüğünü, N0 uygulamasinda $4.62 \mathrm{mg} \mathrm{kg}^{-1}$ olan stigmasterol konsantrasyonunun N130 uygulamasında 4.97 mg kg-1'a çıktığını, N0 uygulamasında $1769 \mathrm{mg} \mathrm{kg}^{-1}$ olan sitosterol konsantrasyonunun ise N130 uygulamasında $1495 \mathrm{mg}$ $\mathrm{kg}^{-1}$ 'e düştügünü bildirilmişlerdir. Pavlik et al. (2010), ise farklı formlarda ve farklı dozlarda N uygulamasının misır tanesindeki $\beta$-sitosterol konsantrasyonuna etkisini araştırmışlardır. Araştırıcılar amonyum nitrat uygulamasına göre üre amonyum nitrat uygulamasının mısır tanesindeki $\beta$-sitosterol konsantrasyonlunu \%94 oranında arttırdığını bildirmişlerdir. Aroiee and Omidbaigi (2002), tıbbi kabak bitkisine beş farklı $(0,75,150,225$ ve $300 \mathrm{~kg}$ $\mathrm{ha}^{-1}$ ) azot uygulamasının dane verimi, yeşil aksam klorofil, $N$ ve $\beta$-sitositerol konsantrasyonlarına etkisini araştırmışlardır. Araştırıcılar kontrol uygulamasında göre artan azot uygulamalarının dane verimini arttırdığını, en yüksek dane veriminin $75 \mathrm{~kg} \mathrm{ha}^{-1} \mathrm{~N}$ uygulamasında olduğunu, yeşil aksam klorofil ve N konsantrasyonunda meydana gelen en yüksek artışın

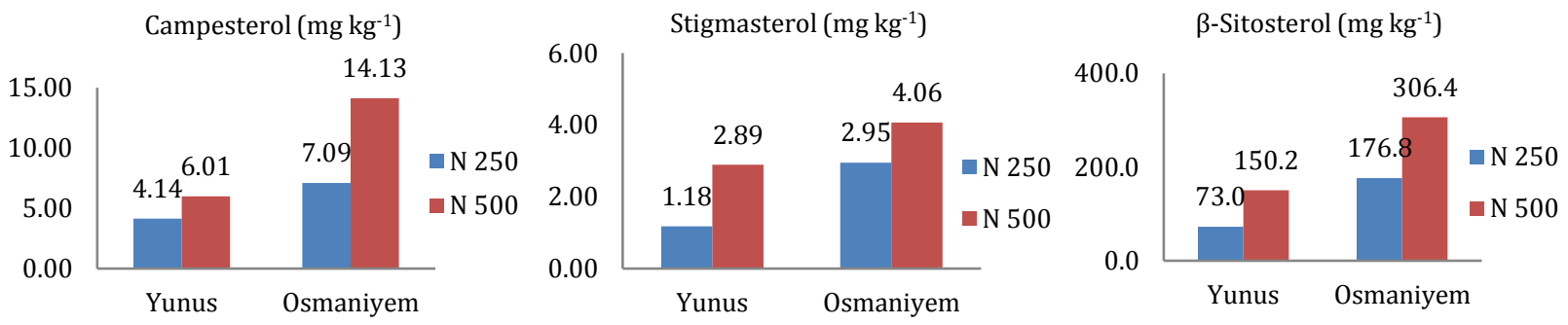

azotun 225 ve $300 \mathrm{~kg} \mathrm{ha}^{-1}$ dozlarında olduğunu bildirmişlerdir. Yeşil aksam $\beta$-sitositerol konsantrasyonunun ise artan azot uygulaması ile önemli ölçüde arttığını ve en fazla artışın ise azotun $150 \mathrm{~kg} \mathrm{ha}^{-1}$ dozunda olduğunu bildirmişlerdir. Verardo et al. (2012), ceviz ağaçlarına üç yıl boyunca hektara 0 , 100 ve $200 \mathrm{~kg}$ azot uygulaması ve bu N uygulamalarının meyve fitosterol içeriğine etkisini araştırmışlardır. Araştırıcıların elde ettikleri sonuçlara göre azot uygulamasının cevizdeki fitosteroller (campesterol, sitosterol ve sitostanol) üzerinde istatistiki olarak etkisinin bulunmadığını bildirmişlerdir. Azot uygulamaları ile Yunus ve Osmaniyem çeşitlerinin tane K konsantrasyonlarında düşüşler meydana gelmiştir. Yunus çeşidinin tane P, Fe ve Zn konsantrasyonlarında önemli bir değişim meydana gelmemiş, Osmaniyem çeşidinin ise Fe konsantrasyonunda önemli $(\mathrm{p}<0.05)$ artışın olduğu, buna karşın $\mathrm{P}$ ve Zn konsantrasyonlarında meydana gelen değişimin ise önemli olmadı̆̆ı görülmüștür.

Şekil 2. Topraktan (N250) ve toprak+yapraktan (N500+\%0.5 üre) N uygulamalarının tane Campesterol, Stigmasterol ve Betasitosterol konsantrasyonlarına etkisi

Çizelge 3. Topraktan (N250) ve toprak+yapraktan (N500+\%0.5 üre) N uygulamalarının tane campesterol, stigmasterol ve betasitosterol konsantrasyonu üzerine etkisinin varyans analiz tablosu

\begin{tabular}{|c|c|c|c|c|c|c|}
\hline Sterol & $\begin{array}{l}\text { Varyasyon } \\
\text { kaynakları }\end{array}$ & $\begin{array}{c}\text { Serbestlik } \\
\text { derecesi }\end{array}$ & Kareler toplamı & $\begin{array}{c}\text { Kareler ortala- } \\
\text { ması }\end{array}$ & F değeri & Önemlilik \\
\hline \multirow{4}{*}{ Campesterol } & Azot dozu & 1 & 79.39 & 79.39 & 930.99 & 0.0001 \\
\hline & Çeșit & 1 & 122.59 & 122.59 & 1437.68 & 0.0001 \\
\hline & Doz*çeşit & 1 & 26.76 & 26.76 & 313.88 & 0.0001 \\
\hline & Hata & 12 & 1.02 & 0.09 & & \\
\hline \multirow{4}{*}{ Stigmasterol } & Azot dozu & 1 & 7.96 & 7.96 & 3725.96 & 0.0001 \\
\hline & Çeșit & 1 & 8.67 & 8.67 & 4054.66 & 0.0001 \\
\hline & Doz*çeşit & 1 & 0.36 & 0.36 & 167.07 & 0.0001 \\
\hline & Hata & 12 & 0.03 & 0.00 & & \\
\hline \multirow{4}{*}{ Betasitosterol } & Azot dozu & 1 & 42776.27 & 42776.27 & 3223.37 & 0.0001 \\
\hline & Çeșit & 1 & 67571.57 & 67571.57 & 5091.80 & 0.0001 \\
\hline & Doz*çeşit & 1 & 2748.57 & 2748.57 & 207.12 & 0.0001 \\
\hline & Hata & 12 & 159.25 & 13.27 & & \\
\hline
\end{tabular}

**: $\mathrm{p}<0.01{ }^{*}: \mathrm{p}<0.05$ önem seviyesinde

Azot uygulamaları ile hem Yunus hem de Osmaniyem çeşitlerinin tane $\mathrm{N}$ konsantrasyon artışına paralel olarak, tane Campesterol, Stigmasterol ve Betasitos- terol konsantrasyonlarında da önemli artışların olduğu görülmüştür. Elde edilen bu sonuçlardan N'un Campesterol, Stigmasterol ve Betasitosterol yapısına katılma ihtimalinin yüksek olduğu görülmektedir. 


\section{Kaynaklar}

Abidi, S. L., 2001. Chromatographic analysis of plant sterols in foods and vegetable oils. Journal of Chromatography A, 935(1-2):173-201.

Anonim, 2012. En çok kullanılan tahıllar. (Web sayfası: http://faostat.fao.org/), (Erişim Tarihi: 10.08.2016).

AOAC, 2000. Association of Official Analytical Chemists. Official Method of Analysis. 13th edition. Washington DC.

Aroiee, H., Omidbaigi, R., 2002. Effects of nitrogen fertilizer on productivity of medicinal pumpkin, XXVI International Horticultural Congress: The Future for Medicinal and Aromatic Plants (11-17 August, 2002, Toronto, Canada), 415-419.

Bly, A. G., Woodard H. J., 2003. Foliar nitrogen application timing influence on grain yield and protein concentration of hard red winter and spring wheat. Agronomy Journal, 95(2): 335-338.

Bremner, J. M., 1965. “Total nitrogen, 1149-1178”. In: C.A. Black (ed.) Methods of soil analysis, Part 2. American Society of Agronomy, Inc. Madison, Wisconsin, USA, $1759 \mathrm{pp}$.

Coşkun, T., 2005. Fonksiyonel besinlerin sağlığımız üzerine etkileri. Çocuk Sağlı̆̆ı ve Hastalıkları Dergisi, 48 (1): 61-84.

El, S. N., 2008. Gıda bileşenlerinin beslenme açısından önemi. Beslenme ders notu. Ege Üniversitesi Mühendislik Fakültesi (Web sayfası: http://food. ege.edu.tr/files/gidabeslenmedersnotu.pdf), (Erişim Tarihi: 13.09.2016).

Gül, M. K., Egesel, C. Ö., Tayyar, Ş., Kahrıman, F., 2007. Phytosterol in rapeseed. International Journal of Agriculture and Biology, 9(2): 250-253.

Haile, D., Nigussie, D., Ayana, A., 2012. Nitrogen use efficiency of bread wheat: Effects of nitrogen rate and time of application. Journal of soil science and plant nutrition 12(3): 389-410.

Hewitt, E. J., Smith, T. A., 1974. Plant Mineral Nutrition. English Universities Press Ltd., London, 298 pp.
Kacar, B., İnal, A., 2008. Bitki Analizleri. Nobel Yayın Dağıtım Ltd.Şti., Ankara 892 s.

Kotancılar, G., Çelik, İ., Ertugay, Z., 1995. Ekmeğin besin değeri ve beslenmedeki önemi. Ankara Üniversitesi, Ziraat Fakültesi Dergisi, 26 (3): 431-441.

Moreau, R. A., Whitaker, B. D., Hicks, K. B., 2002. Phytosterols, phytostanols, and their conjugates in foods: Structural diversity, quantitative analysis and health promoting uses. Progress in Lipid Research, 41(6): 457-500.

Nurmi, T., 2012. Variation of Phytosterols and Steryl Ferulates In Wheat Grains and Fractions. Department of Food and Environmental Sciences, University of Helsinki, Academic Dissertation. Helsinki, 118 pp.

Nurmi, T., Nyström, L., Edelmann, M., Lampi, A. M., Piironen, V., 2008. Phytosterols in wheat genotypes in the HEALTHGRAIN diversity screen. Journal of Agricultural and Food Chemistry, 56 (21): 9710-9715.

Pavlik, M., Pavlikova, D., Balik, J., Neuberg, M., 2010. The contents of amino acids and sterols in maize plants growing under different nitrogen conditions. Plant soil Environment, 56 (3): 125-132.

Piironen, V., Lindsay, D. G., Miettinen, T. A., Toivo, J., 2000. Plant sterols: biosynthesis, biological function and their importance to human nutrition. Journal of the Science of Food and Agriculture, 80(7): 939-966.

Rudkowska, I., 2010. Plant sterols and stanols for healthy ageing. Maturitas, 66(2): 158-162.

Taşan, M., 2008. Tahıl ve ürünlerinde fitosteroller, Türkiye 10. Gida Kongresi (21-23 Mayıs 2008, Erzurum) Bildirileri, 399-402.

Verardo, V., Riciputi, Y., Sorrenti, G., Ornaghi, P., Marangoni, B., Caboni, M. F., 2012. Effect of nitrogen fertilisation rates on the content of fatty acids, sterols, tocopherols and phenolic compounds, and on the oxidative stability of walnuts. LWT-Food Science And Technology, 50 (2): 732-738.

Xu, G., Fan, X., Miller, A. J., 2012. Plant nitrogen assimilation and use efficiency. Annual review of plant biology, 63: 153-182. 